\title{
HUBUNGAN DUKUNGAN SUAMI DENGAN PEMBERIAN ASI EKSKLUSIF DI PUSKESMAS KOTA RANTAUPRAPAT KABUPATEN LABUHANBATU TAHUN 2016
}

\author{
Fitriani Nasution \\ STIKes Indah, Indonesia
}

Article Info

Keywords:

Husband Support

Exclusive ASI

\begin{abstract}
Exclusive breastfeeding is the most effective intervention to prevent child deaths but according to the Indonesian Health Demographic Survey (SDKI), the rate of exclusive breastfeeding has declined over the past decade. Rantauprapat City Health Center had the lowest exclusive breastfeeding coverage in 2013 compared to other health centers, which was $11.50 \%$. The purpose of this study was to determine the relationship between husband's support and exclusive breastfeeding at the Rantauprapat City Health Center in Labuhan Batu Regency in 2016. The type of analytic survey research was cross sectional approach. The population is all mothers who have babies aged 7-12 months as many as 710 people, while the sample is 106 people. Data collection is done by interview. Data analysis with Chi Square. The results showed $p=0.014<0.05$, meaning that there was a significant relationship between husband's support and exclusive breastfeeding. at the Rantauprapat City Health Center. It is recommended to health workers in the City of Rantauprapat Health Center to further increase efforts to provide exclusive breastfeeding through direct counseling to pregnant women and hopefully be accompanied by her husband, so that the husband can provide support to mothers in exclusive breastfeeding.
\end{abstract}

This is an open access article under the CC BY-SAlicense.

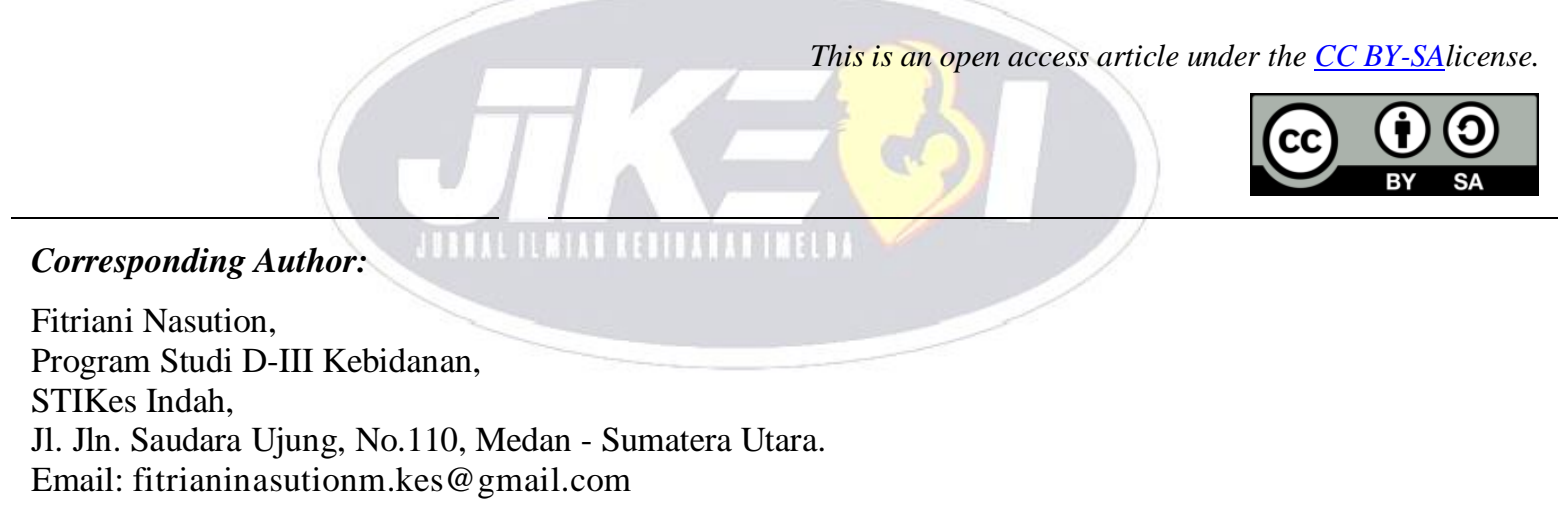

\section{INTRODUCTION}

Air Susu Ibu (ASI) merupakan makanan terbaik bagi bayi baru lahir sampai dengan umur 6 bulan dan meneruskan pemberian ASI sampai anak berumur 24 bulan (Pusat Komunikasi Publik, 2011). Pemberian ASI eksklusif adalah intervensi paling efektif untuk mencegah kematian anak, namun menurut Survei Demografi Kesehatan Indonesia (SDKI), tingkat pemberian ASI eksklusif telah menurun selama dekade terakhir. Ada banyak hambatan ibu menyusui di Indonesia, salah satu diantaranya suami yang tidak mendukung pemberian ASI eksklusif. Beberapa ibu juga takut menyusui karena akan menyakitkan.

Di Indonesia cakupan pemberian ASI ekskusif pada bayi 0-6 bulan berfluktuatif. Pada tahun 2012, cakupan pemberian ASI eksklusif bayi 0-6 bulan sebesar 32\% mengalami kenaikan menjadi $42 \%$. Ada19 
propinsi yang mempunyai persentase pemberian ASI eksklusif 'di atas angka nasional (54,3\%), dimana persentase tertinggi terdapat pada Propinsi Nusa Tenggara Barat $(79,7 \%)$ dan persentase terendah pada propinsi Maluku (25,2\%). Secara global pemberian ASI eksklusif < 6 bulan kurang dari 40\%, dengan demikian angka nasional ASI eksklusif di Indonesia masih lebih tinggi dibandingkan angka global. (Kemenkes RI, 2014).

Profil kesehatan Dinas Kesehatan Propinsi Sumatera Utara tahun 2011 menunjukkan persentase pemberian ASI eksklusif adalah 26,67\%, terjadi sedikit peningkatan bila dibandingkan dengan tahun 2010 yang hanya mencapai $25,43 \%$. Cakupan tersebut kembali menurun di tahun 2012 menjadi 20,33\% dan naik kembali menjadi 27,06\% di tahun 2013 dan 34,56\% di tahun 2014.

Menurut Dirjen Gizi dan KIA, keberhasilan ibu menyusui untuk terus menyusui bayinya sangat ditentukan oleh dukungan dari suami, keluarga, petugas kesehatan, masyarakat serta lingkungan kerja (Budiharja, 2011).

Roesli (2000) menyatakan bahwa dari semua dukungan bagi ibu menyusui, dukungan suami adalah dukungan yang paling berarti bagi ibu. Suami dapat berperan aktif dalam keberhasilan ASI eksklusif karena suami akan turut menentukan kelancaran refleks pengeluaran ASI (milk let down reflex) yang sangat dipengaruhi oleh keadaan emosi atau perasaan ibu. Suami dapat memberikan dukungan secara emosional dan bantuan - bantuan yang praktis. Dukungan suami merupakan salah satu faktor penting dalam memicu refleks oksitoksin. Peran ayah atau suami sangat besar dalam mempengaruhi keadaan emosi dan perasaan ibu, hal ini mempengaruhi refleks oksitoksin sehingga produksi ASI meningkat (Adiningsih, 2004).

Penelitian Mardeyanti (2007) di Tangerang menyatakan bahwa 60\% ibu tidak memberikan ASI eksklusif karena tidak mendapatkan dukungan suami. Secara proporsi ibu yang memberi ASI eksklusif, 44\% mendapat dukungan dari suami (Hadinegoro, 2007).

Dukungan keluarga terutama suami dapat menentukan keberhasilan atau kegagalan menyusui, sebab dukungan suami akan menimbulkanrasa nyaman pada ibu sehingga akan mempengaruhi produksi ASI serta meningkatkan semangat dan rasa nyaman dalam menyusui (Adiningsih, 2004). Dalam kenyataan masih banyak suami yang berpendapat bahwa menyusui adalah urusan ibu dengan bayinya, sehingga kurang peduli.

Penelitian lain yang berjudul Hubunngan Pengetahuan dan Sikap Ibu Dengan Pemberian ASI Eksklusif Di Klinik Ananda Medan menyatakan dari hasil penelitian dengan menggunakan rumus uji chi square didapat nilai $\mathrm{p}$ value $0,001<0,05$. Nilai $\mathrm{p}$ value yang didapat lebih kecil dibandingkan nilai $\alpha(0,05)$ yang berarti ada hubungan antara pengetahuan ibu dengan pemberian ASI Eksklusif di Klinik Ananda Medan (Sinaga, 2017).

Hasil survey awal penelitian yang dilakukan pada tanggal 04 Februari 2016 adalah Kabupaten Labuhanbatu terdiri dari 9 (Sembilan) Kecamatan dengan jumlah Puskesmas sebanyak 15 dan Puskesmas Pembantu (Pustu) sebanyak 48. Capaian cakupan bayi yang diberi ASI eksklusif di Kabupaten Labuhanbatu dari tahun 2009 -2014 sangat fluktuatif dimana pada tahun 2009 cakupan ASI eksklusif menurun sampai tahun 2011 menjadi 39,04\% dan pada tahun 2012 capaian cakupan naikkembali menjadi 45,50\%, turun kembali di tahun 2013 menjadi 22,01\% dan meningkat kembali menjadi 41,76\% di tahun 2014.

Pada tahun 2013 Wilayah Kerja Puskesmas Kota Rantauprapat mempunyai capaian cakupan pemberian ASI eksklusif yang paling rendah dibandingkan puskesmas yang lainnya, yakni sebesar 11,50\% walaupun pada tahun 2014 mengalami kenaikan yang signifikan yakni 47,72\% dari jumlah bayi (0-6 bulan) sebanyak 241 bayi. Tujuan penelitian ini adalah untuk mengetahui hubungan dukungan suami dengan pemberian ASI Eksklusif di Puskesmas Kota Rantauprapat Kabupaten Labuhanbatu tahun 2016.

\section{RESEARCH METHOD}

Jenis penelitian adalah penelitian survei analitik dengan pendekatan cross sectional yang dilakukan di Wilayah Kerja Puskesmas Kota Rantauprapat Kecamatan Rantau Utara Kabupaten Labuhanbatu yang terdiri dari 7 Kelurahan yaitu Kelurahan Kota, Kelurahan Kartini, Kelurahan Cendana, Kelurahan Binaraga, Kelurahan Siringo-ringo, Kelurahan Sirandorung, dan Padang Bulan. Dilaksanakan pada bulan November 2015 sampai dengan Agustus 2016.

Populasi adalah seluruh ibu yang mempunyai bayi usia 7-12 bulan yang berada di wilayah kerja Puskesmas Kota Rantauprapat Kabupaten Labuhanbatu yang berjumlah sebanyak 710 responden, berdasarkan data terakhir pada bulan April 2016, dengan asumsi responden masih mengingat pemberian ASI eksklusif pada bayinya. Jumlah sampel yang dibutuhkan 106 responden. Teknik pengambilan sampel dilakukan secara proportional stratified random sampling. Instrumen penelitian berupa kuesioner dan dokumen yang berhubungan dengan penelitian. Analisis data dilakukan secara chi square. 


\section{RESULTS AND ANALYSIS Karakteristik Responden}

Karakteristik individu dalam penelitian ini adalah keseluruhan data dan informasi responden yang terdiri dari umur, jumlah anak, tingkat pendidikan, jenis pekerjaan dan penghasilan yang disajikan dalam Tabel 1 berikut.

Tabel 1. Karakteristik Responden

\begin{tabular}{|c|c|c|c|}
\hline \multirow[t]{2}{*}{ No } & \multirow[t]{2}{*}{ Karakteristik resonden } & \multicolumn{2}{|c|}{ Jumlah } \\
\hline & & $\mathbf{N}$ & $\%$ \\
\hline 1 & Umur & & \\
\hline & $<35$ Tahun & 83 & 78,3 \\
\hline & $\geq 35$ Tahun & 23 & 21,7 \\
\hline & Total & 106 & 100 \\
\hline 2 & Jumlah Anak & & \\
\hline & $\leq 2$ anak & 91 & 85,8 \\
\hline & $>2$ anak & 15 & 14,2 \\
\hline & Total & 106 & 100 \\
\hline 3 & Pendidikan & & \\
\hline & Tidak tamat SD & 1 & 9 \\
\hline & SD & 7 & 6,6 \\
\hline & SMP & 37 & 34,9 \\
\hline & SMA & 49 & 46,2 \\
\hline & D3 & 8 & 7,5 \\
\hline & SARJANA & 4 & 3,8 \\
\hline & Total & 106 & 100 \\
\hline 4 & Pekerjaan & & \\
\hline & Bekerja & 74 & 69,8 \\
\hline & Tidak Bekerja & 32 & 30,2 \\
\hline & Total & 106 & 100 \\
\hline 5 & Penghasilan & 8 & \\
\hline & $\leq 2.085 .050$ & 54 & 50,9 \\
\hline & $>2.085 .050$ & 52 & 49,1 \\
\hline & Total & 106 & 100 \\
\hline
\end{tabular}

Berdasarkan tabel 1 di atas menunjukkan bahwa berdasarkan umur, proporsi umur responden mayoritas pada < 35 tahun sebesar 78,3\%. Hal ini karena bukan hanya faktor usia saja yang dapat mempengaruhi pengetahuan, sikap dan tindakan ibu untuk memberikan ASI eksklusif kepada bayinya, tetapi juga faktor-faktor lain seperti budaya, suku dan, lingkungan.

Jumlah anak mayoritas $\leq 2$ orang sebesar $85,8 \%$. Jumlah anak akan mempengaruhi pemberian ASI pada bayi jika jarak lahir antar anak sangat dekat maka pemberian ASI tidak bisa optimal.

Suku mayoritas Jawa sebanyak (54,7\%). Faktor suku juga berpengaruh dalam pemberian ASI eksklusif, responden yang bersuku Jawa, pada umumnya bayi pada usia 4 bulan sudah diberi makanpisang hijau untuk menambah asupan makan bayi supaya bayi kenyang dan tidak rewel, pada suku Batak diberi madu untuk meningkatkan daya tahan tubuh bayi sehingga bayi tidak mudah sakit, dan pemberian air tajin nasi untuk menambah asupan pangan bayi, sedangkan pada suku Cina tidak ditemukan ibu yang memberikan ASI eksklusif pada bayinya karena berhubungan dengan estetika bentuk payudara, suku Cina mempercayai jika menyusui akan menyebabkan payudara ibu menjadi kendur.

Proporsi pendidikan mayoritas SMA sebesar $46,2 \%$, sedangkan pekerjaan paling banyak bekerja sebesar $69,8 \%$. Ada beberapa ibu yang mengeluh bahwa memompa ASI adalah pekerjaan yang merepotkan dan menyakitkan. Di daerah perkotaan ada kecenderungan makin banyak ibu yang tidak memberi ASI eksklusif pada bayinya dengan alasan ibu bekerja. Walaupun sebenarnya ibu bekerja dapat memberikan ASI eksklusif pada bayinya bila ibu tersebut memiliki pengetahuan tentang menyusui, memerah ASI serta menyimpan ASI (Soetjiningsih, 2001).

Penghasilan mayoritas < Rp. 2.085 .050 sebesar 50,9\%. Namun sebagian besar tidak memberikan ASI eksklusif malah memberikan susu formula kepada bayinya. Seharusnya apabila ibu menyusui secara eksklusif kepada bayi selama 0-6 bulan tanpa memberikan susu formula dan cairan lain kemudian tetapmemberikan ASI sampai bayi usia 24 bulan, maka hal ini dapat mengurangi pengeluaran belanja keluarga. Ibu cukup dengan mengkonsumsi makanan yang bergizi seimbang.

\section{Analisis Univariat}


Hasil penelitian setiap pertanyaan kepada responden sebagaimana di jabarkan pada Tabel 2 berikut:

Tabel 2. Distribusi Frekuensi Pemberian ASI Eksklusif di Puskesmas Kota Rantauprapat Tahun 2016

\begin{tabular}{lcc}
\hline Pemberian ASI & \multicolumn{2}{c}{ Jumlah } \\
\cline { 2 - 3 } Eksklusif & $\mathbf{N}$ & Persentase (\%) \\
\hline Eksklusif & 9 & 8,5 \\
\hline Tidak Eksklusif & 97 & 91,5 \\
\hline Jumlah & 106 & 100,0 \\
\hline
\end{tabular}

Berdasarkan Tabel 2 Pemberian ASI eksklusif di Puskesmas Kota Rantauprapat diperoleh bahwa ibu yang ASI eksklusif sebanyak 9 orang (8,5\%) dan yang tidak ASI eksklusif sebanyak 97 orang (91,5\%).

Tabel 3. Distribusi Frekuensi Dukungan Suami di Puskesmas Kota Rantauprapat Tahun 2016

\begin{tabular}{lcc}
\hline Dukungan Suami & \multicolumn{2}{c}{ Jumlah } \\
\cline { 2 - 3 } & $\mathbf{N}$ & Persentase (\%) \\
\hline Baik & 51 & 48,1 \\
\hline Kurang Baik & 55 & 51,9 \\
\hline Jumlah & 106 & 100,0 \\
\hline
\end{tabular}

Berdasarkan Tabel 3 di atas Dukungan Suami tentang pemberian ASI eksklusif di Puskesmas Kota Rantauprapat diperoleh bahwa ibu yang mempunyai dukungan suami baik sebanyak 51 orang $(48,1 \%)$ dan yang mempunyai dukungan suami tidak baik sebanyak 55 orang $(51,9 \%)$.

\section{Analisis Bivariat \\ Hubungan Dukungan Suami dengan Pemberian ASI Eksklusif di Puskesmas Kota Rantauparapat}

Berdasarkan Tabel 4 dibawah ini menunjukkan bahwa dari 51 orang yang mempunyai dukungan suami baik, ada 8orang $(15,7 \%)$ yang memberikan ASI eksklusif dan 43orang $(84,3 \%)$ yang tidak memberikan ASI eksklusif. sebanyak 55 orang yang mempunyai dukungan suami tidak baik, ada 1 orang $(1,8 \%)$ yang memberikan ASI eksklusif dan 54 orang $(98,2 \%)$ yang tidak memberikan ASI eksklusif. Hasil uji Chi-Square menunjukkan bahwa nilai $\mathrm{p}=0,014<0,05$ yang artinya ada hubungan yang signifikan antara dukungan suami dengan pemberian ASI eksklusif.

Sesuai dengan penelitian Zakiyah (2012) bahwa ada hubungan dukungan suami dengan pemberian ASI eksklusif. Ibu dengan dukungan suami sedang berpeluang 1,8 kali lebih besar dibandingkan ibu dengan dukungan suami rendah. Ibu yang memiliki dukungan suami baik berpeluang 4,95 kali memberikan ASI eksklusif dibandingkan ibu dengan dukungan suami rendah. Sementara itu, penelitian yang dilakukan oleh Hadi (2012) di Puskesmas Air tawar Kota Padang juga menyatakan bahwa terdapat hubungan antara dukungan suami yang baik berpeluang memberikan ASI eksklusif 2 kalidaripada ibu yang memiliki dukungan suami yang rendah.

Berdasarkan pernyataan tersebut, hal ini disebabkan karena suami percaya kepada istri sehingga keputusan pemberian ASI ditentukan oleh ibu tanpa campur tangan suami, ditambah dengan kesibukan suami yang bekerja dan tidak memperhatikan pemberian ASI pada bayi. Hal lain yang ditemukan bahwa mayoritas suami tidak menyediakan dana untuk pemeriksaan, perawatan, dan pemenuhan gizi selama menyusui. Hasil ini dapat disimpulkan bahwa suami masih belum bisa memenuhi secara finansial kebutuhan ibu saat menyusui dengan baik, hal ini bisa dikaitkan dengan keadaan sosial ekonomi keluarga. Sebagaimana dapat dilihat pada tabel 4 berikut:

Tabel 4. Hubungan Dukungan Suami dengan Pemberian ASI Eksklusifdi Puskesmas Kota

\begin{tabular}{|c|c|c|c|c|c|c|c|}
\hline \multirow{3}{*}{ Dukungan Suami } & \multicolumn{4}{|c|}{ ASI Eksklusif } & \multirow{2}{*}{\multicolumn{2}{|c|}{ Jumlah }} & \multirow{3}{*}{ Nilai p } \\
\hline & \multicolumn{2}{|c|}{ Eksklusif } & \multicolumn{2}{|c|}{ Tidak Eksklusif } & & & \\
\hline & $\mathbf{N}$ & $\%$ & $\mathbf{n}$ & $\%$ & $\mathbf{n}$ & $\%$ & \\
\hline Baik & 8 & 15,7 & 43 & 84,3 & 51 & 100,0 & \multirow{2}{*}{0,014} \\
\hline Kurang Baik & 1 & 1,8 & 54 & 98,2 & 55 & 100,0 & \\
\hline
\end{tabular}

\section{CONCLUSION}

Berdasarkan tujuan dan hasil penelitian maka dapat disimpulkan bahwa dukungan suami mempunyai hubungan signifikan antara dengan pemberian ASI eksklusif di Puskesmas Kota Rantauprapat dengan nilai $\mathrm{p}<0,05$. Hal ini menunjukkan bahwa suami harus berperan serta aktif dalam memberikan dorongan kepada ibu untuk memberikan ASI eksklusif. 


\section{REFERENCES}

Adiningsih, N. U. 2006. Ayah "Menyusui” Cermin Kesetaraan Gender. Jakarta. Penggagas Forum Studi Pemberdayaan Keluarga.

Budiharja. 2011. Banyak Sekali Manfaat ASI bagi Bayi dan Ibu. www.depkes.go.id. Kementrian Republik Indonesia. Jakarta.

Depkes RI, 2011. Banyak Sekali manfaat ASI bagi Bayi dan Ibu. Jakarta: Pusat Komunikasi Publik Kementrian Kesehatan RI.

Dinas Kesehatan Propinsi Sumatera Utara. 2014. Profil Kesehatan Propinsi Sumatera Utara Tahun 2014. Medan.

Dinas Kesehatan Kabupaten Labuhanbatu. 2013. Profil Kesehatan Kabupaten Labuhanbatu Tahun 2013. Rantauprapat.

Dinas Kesehatan Kabupaten Labuhanbatu. 2014. Profil Kesehatan Kabupaten Labuhanbatu Tahun 2014. Rantauprapat

Hadi, N, Ramadani, M. 2012. Dukungan Suami dalam Pemberian ASI eksklusif diWilayah Kerja Puskesmas Air Tawar Kota Padang, Sumatera Barat. Jurnal Kesmas Vol 4, No 6.

Hadinegoro, dkk. 2007. Pattern dan Influencing Factors of Breastfeding of Working Mothers in Several Areas in Jakarta Pediatrics Indonesia, Volum 47 No. 1.

Mardeyanti. 2007. Pengaruh Karakteristik dan Dukungan Keluarga terhadap Pemberian ASI Eksklusif di Tangerang, Jurnal Kesehatan Masyarakat Nasional Volume 1 dan 2.

Roesli, Utami. 2000. Mengenal ASI Eksklusif. Jakarta : Taurus Agrimidya.

Sinaga, E. S. (2017). Hubungan pengetahuan dan sikap ibu dengan pemberian ASI eksklusif di Klinik Ananda mMedan. Jurnal Ilmiah Kebidanan Imelda, 3(1).

Soetjiningsih. 2001. ASI Petunjuk untuk Tenaga Kesehatan. Jakarta : EGC.

Zakiyah. 2012. Faktor-Faktor Yang Berhubungan Dengan Pemberian Asi Ekslusif Di Keluarahan Semanan Kecamatan Kalideres Jakarta Barat Tahun2012. Skripsi FKM UI. Depok.

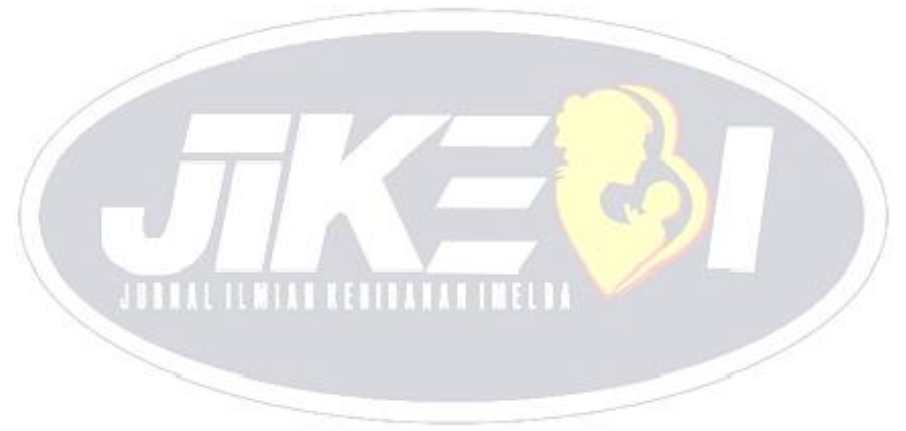

